\title{
PENYUSUNAN 10 KELOMPOK BAHAN VALIDASI SILANG PADA KASUS 197 TITIK CURAH HUJAN DI JAWA TIMUR
}

\author{
Andang Kurniawan ${ }^{1 *}$, Dede Tarmana ${ }^{2}$ \\ ${ }^{1}$ Prodi Klimatologi, Sekolah Tinggi Meteorologi Klimatologi dan Geofisika,Tangerang Selatan \\ ${ }^{2}$ Badan Meteorologi Klimatologi dan Geofisika \\ *Email : andang.kurniawan@bmkg.go.id
}

\begin{abstract}
ABSTRAK
Untuk mendapatkan gambaran spasial suatu parameter lingkungan, diperlukan penentuan metode interpolasi spasial terbaik. Permasalahan muncul karena terdapat banyak sekali jenis metode interpolasi spasial. Untuk menentukan metode interpolasi yang paling sesuai, dapat dilakukan teknik validasi silang. Interpolasi juga penting dalam analisis curah hujan bulanan. Pada kasus interpolasi spasial 197 titik pengamatan curah hujan di Jawa Timur, validasi silang dapat dilakukan dengan menghilangkan sepuluh persen data secara bergantian. Penyusunan bahan validasi silang penting untuk dikembangkan agar terhindar dari terkumpulnya atau berbatasan langsungnya antar titik yang dihilangkan. Tujuan dari studi ini adalah menyusun bahan validasi silang dan menguji kehandalannya. Data koordinat lintang dan bujur dari 197 titik didapatkan dari Stasiun Klimatologi Malang. Peringkat data digunakan sebagai basis penyusunan. Dari sepuluh kelompok bahan validasi silang, tujuh (tiga) grup akan memiliki dua puluh (sembilan belas) data yang dihilangkan. Data yang dihilangkan dari kelompok pertama (sepuluh) adalah data bernomor urut digit terakhir satu (nol). Tiga pendekatan dilakukan untuk mendapatkan peringkat: koordinat saja, klastering, dan pemisahan. Klastering menggunakan jarak euklid tautan lengkap dengan variasi klaster 98, 65, dan 49. Metode pemisahan dilakukan dengan membagi terlebih dahulu titik ke dalam 20 (5x4) kotak. Untuk mengetahui penyebaran yang baik digunakan dua pendekatan, yaitu tidak adanya pertetanggaan terdekat dan jarak yang lebih jauh. Analisis visual dengan bantuan poligon voronoi, plot boks, dan indeks histogram digunakan. Dua indeks (SR dan IK) dikembangkan untuk mengetahui pergeseran distribusi. Pendekatan menggunakan pemisahan merupakan metode yang paling sesuai. Dengan menambahkan sepuluh modifikasi, didapatkan bahan validasi silang yang dapat digunakan untuk uji komparasi metode interpolasi.
\end{abstract}

Kata kunci: validasi silang, poligon voronoi, metode pemisahan

\begin{abstract}
In order having spatial information of some environmental parameter, it is important to decide the best interpolation method. A problem then exist because there are so many spatial intepolation methods. For deciding the most suitable method, cross validation can be the alternative. Interpolation method is an important aspect for monthly rainfall analysis. In the case spacial interpolation for 197 observation points of East Java rainfall, cross validation can be done by removing ten percent alternately. Cross validation material arrangement is important to be improved for avoiding too gathered or having direct border between removed points. The aim of this study is arranging cross validation material and test its reliability. Longitude and latittude coordinate data from 197 rainfall observation points in East Java is got from Malang Climatological Station. Rank of data is used as arrangement basis. From ten cross validation group, seven (three) will have twenty (nineteen) removed data. The removed data from first (tenth) group are data whose last digit number of one (zero). Three approach is used for making the rank: only coordinate, clustering, and separation. Clustering uses euclidean distance complete linkage with cluster variation 98, 65, and 49. Separaion method is done by dividing the points to 20 (5x4) box. To understand the best distribution, two approach is used, no nearest neighbourhood and more distant. Visual analysis assisted with voronoi polygon, box plot, and histogram indices is used. Two indices (SR and IK) is developed for measuring distribution shifting. Separation method shows the most suitable result. By adding ten modifications, cross validation material which can be used as interpolation method comparison test is arranged.
\end{abstract}

Keywords: cross validation, voronoi polygon, separation method 


\section{PENDAHULUAN}

Kebutuhan akan informasi dalam bentuk spasial menuntut peningkatan kemampuan instansi penyedia informasi untuk menggunakan metode interpolasi spasial. Metode interpolasi spasial atau disebut juga model prediksi spasial (Hengl, 2009) merupakan sebuah metode untuk meluaskan informasi dari titik pengamatan menjadi informasi pada seluruh ruang. Dengan menggunakan metode interpolasi spasial, gambaran umum pola parameter lingkungan dalam suatu wilayah dapat dilihat secara lebih jelas. Kendala muncul ketika metode interpolasi spasial begitu banyak. Dalam beberapa studi (Adhikary dkk., 2017; Borges dkk., 2015;Taesombat dan Sriwongsitanon, 2009) disebutkan bahwa interpolasi dapat menggunakan metode ordinary kriging, ordinary co-kriging, kriging with exernal drift, inverse distance weight, spline, universal kriging, regression kriging, regresi linear, dan poligon thiessen. Penentuan metode interpolasi terbaik menjadi penting untuk dikaji.

Interpolasi juga penting dalam analisis curah hujan bulanan. Sebuah studi mengenai seberapa luas sebenarnya pengamatan curah hujan telah dilakukan untuk mempelajari pola hujan global menunjukkan bahwa cakupan pengamatan global curah hujan tidak lebih dari 3000 meter persegi (Kidd dkk., 2017). Hal ini sejalan dengan fakta bahwa pengamatan curah hujan tidak mungkin dilakukan pada seluruh titik di muka bumi. Pada akhirnya data curah hujan harus diperlakukan sebagai sebuah sampel, bukan populasi. Hasil pengamatan saja belum mampu menunjukkan gambaran komprehensif tentang curah hujan sehingga masih diperlukan teknik analisis lain.

Untuk mendapatkan metode mana yang paling sesuai digunakan dalam interpolasi spasial curah hujan, dapat dilakukan validasi silang. Salah satu metode validasi silang yang biasa digunakan adalah leave one out (Majani, 2007). Namun metode tersebut hanya mampu menyelidiki dampak penghilangan satu titik dan itu pun masih memiliki faktor bias tertentu (Falivane dkk., 2010). Di sisi lain, terdapat 197 titik pengamatan curah hujan yang dianalisis secara rutin oleh Stasiun Klimatologi Malang, sehingga leave one out menghabiskan sumber daya komputasi yang lebih banyak. Sehingga metode validasi silang dengan menghilangkan sepuluh persen data dapat dilakukan sebagai alternatif, seperti yang dilakukan pada studi Bostan dkk. pada 2012 (Bostan dkk., 2012).

Permasalahan yang ada adalah bagaimana membuat sepuluh persen data yang dihilangkan tidak berkumpul pada suatu tempat atau dengan kata lain lebih merata. Karena yang akan diuji adalah metode interpolasi, perlu diperhatikan pula bahwa titik-titik yang dihilangkan tidak berbatasan langsung satu sama lain. Studi kasus dengan menggunakan data di Jawa Timur dilakukan sebagai contoh kajian penyusunan bahan validasi silang dengan menghilangkan sepuluh persen data secara bergantian.

\section{METODE PENELITIAN}

Data yang digunakan dalam studi ini adalah data 197 titik pos pengamatan curah hujan di Jawa Timur. Titik-titik koordinat yang berupa lintang dan bujur didapatkan dari Stasiun Klimatologi Malang. Adapun dalam penelitian ini, ketinggian (elevasi) tidak dimasukkan sebagai dimensi ke tiga. Sebagai catatan, sebelum diolah lebih lanjut, data diurutkan dari kecil ke besar berdasarkan bujur kemudian lintang. Sebagai catatan lebih

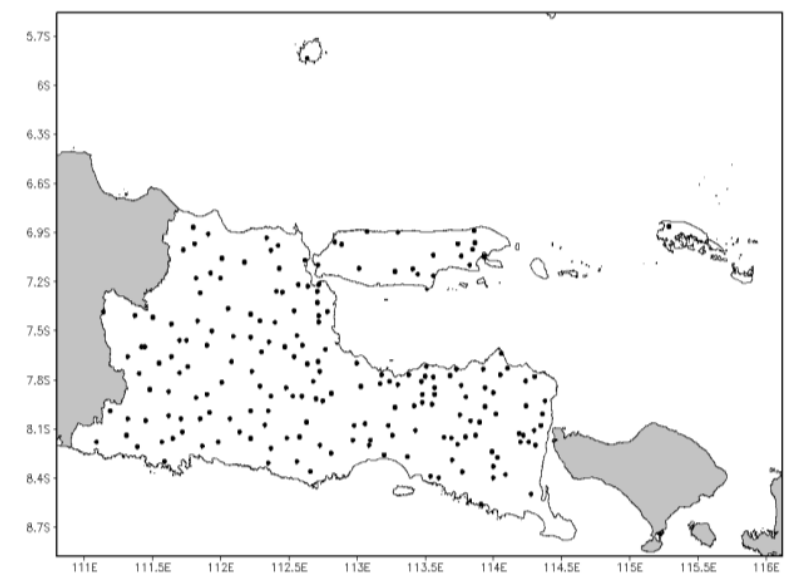

Gambar 1. 197 titik pengamatan curah hujan dan wilayah analisis Jawa Timur. 
lanjut, semua kata terkait urutan dalam studi ini didefinisikan dari kecil ke besar.

Validasi silang yang akan digunakan adalah validasi silang yang membagi 197 data menjadi sepuluh kelompok. Tujuh kelompok akan memiliki anggota berjumlah 177 (=19720) titik sedangkan tiga kelompok lainnya akan memiliki 178 (=197-19) titik. Artinya setiap kelompok terdiri sekitar 90\% (177/197 dan 178/197) titik dari keseluruhan data (S).

Untuk menghilangkan sekitar $10 \%$ data, digunakan mekanisme sebagai berikut.

1. Data diurutkan menggunakan urutan tertentu.

2. Kelompok pertama (g1) adalah kelompok tanpa data urutan pertama, ke-11, ke21 , ...., ke-171, ke-181, sampai dengan ke-191.

3. Kelompok ke dua (g1) sampai dengan kelompok ke tujuh (g7) menggunakan mekanisme yang sama.

4. Kelompok ke delapan (g8) adalah kelompok tanpa data urutan ke-8, ke-18, ke-28, ...., ke-168, ke-178, hanya sampai dengan ke-188. Begitu juga dengan kelompok ke sembilan (g9).

5. Kelompok ke sepuluh (g10) adalah kelompok tanpa data urutan ke-10, ke-20, ke-30, ...., ke-170, ke-180, sampai dengan ke-190.

6. g1 sampai dengan g7 memiliki masingmasing 177 titik sedangkan g8 sampai dengan g10 memiliki masing-masing 178 titik.

Urutan peringkat didapatkan dengan menggunakan tiga pendekatan. Pendekatan pertama hanya menggunakan data koordinat lintang dan bujur saja. Artinya, 197 data diurutkan berdasarkan bujur kemudian lintang dan sebaliknya. Dari dua urutan didapatkan g1 sampai dengan g10 dalam kode LON (bujur kemudian lintang) dan kode LAT (lintang kemudian bujur).

Pendekatan ke dua dilakukan dengan menambahkan klastering sehingga prioritas pengurutan menjadi hasil klastering kemudian bujur dan terakhir lintang. Bujur diutamakan karena persebaran data di Jawa Timur berupa pola yang lebih memanjang dari Barat ke Timur dari pada Utara ke
Selatan (lihat Gambar 1). Klastering dilakukan karena diasumsikan mampu membuat kelompok-kelompok yang terkumpul. Setelah terkumpul, dengan mekanisme yang sudah dijelaskan sebelumnya, diharapkan titik-titik yang dihilangkan akan berjauhan.

Adapun metode klastering yang dipakai dalam studi ini adalah complete linkage atau tautan lengkap. Metode ini menggunakan jarak rata-rata dari kumpulan titik sebagai dasar klastering selanjutnya. Klaster yang dibentuk kemudian dieksperimenkan sebagai berikut, yaitu 98 klaster $(98 / 197 \approx 50 \%), 65$ $(65 / 197 \approx 33 \%)$, dan $(45 / 197 \approx 25 \%)$. Adapun formula secara umum dari tautan lengkap adalah sebagai berikut (Wilks, 2006).

$$
d_{G_{1}, G_{2}}=\frac{1}{n_{1} n_{2}} \sum_{i=1}^{n_{1}} \sum_{j=1}^{n_{2}} d_{i, j}
$$

$d_{G_{1}, G_{2}}$ adalah jarak antar klaster, $\mathrm{n}_{1}$ dan $\mathrm{n}_{2}$ merupakan jumlah anggota dalam klaster, sedangkan $d_{i, j}$ merupakan jarak dalam dimensi í dan İ. Jarak yang dipakai adalah jarak euklid. Pendekatan jarak ini sering dipakai untuk mengkaji fenomena statistika atau fisika (Aires dan Prigent, 2007). Jarak diformulasikan sebagai berikut.

$$
D_{E}\left(y^{0}, y\right)=\left[\left(y^{0}-y\right)^{t} \cdot\left(y^{0}-y\right)\right]^{-2}
$$

atau sama dengan

$\operatorname{jarak}(a, b)=\sqrt{\left(\text { bujur }_{a}-\text { bujur }_{b}\right)^{2}+\left(\text { lintang }_{a}-\operatorname{lintang}_{b}\right)^{2}}$

Hasil klastering yang berupa identitas untuk tiap datum berupa angka klaster (dari 1 sampai dengan 49/65/98/jumlah klaster) kemudian digunakan sebagai prioritas urutan utama disusul dengan bujur lalu lintang. Untuk mempermudah analisis, hasil urutan dari variasi jumlah klaster 98, 65, dan 49 secara berurutan diberi kode K98, K65, dan K49.

Pendekatan ke tiga dilakukan dengan menggunakan metode pemisahan. Melihat 
kondisi Jawa Timur yang relatif memanjang Barat ke Timur dan pembagian kelompok menjadi 10, maka pemisahan dilakukan dengan membagi 197 titik menjadi 20 kelompok berdasarkan koordinat terlebih dahulu. Dengan demikian, ketika penghilangan dilakukan, maka antar titik yang dihilangkan akan berjauhan. Perincian metodenya adalah sebagai berikut.

1. 197 titik diurutkan berdasarkan bujur dan dipisah ke dalam lima kelompok. Datum pertama sampai dengan ke-40 dijadikan kelompok terpisah. Hal identik dilakukan sampai datum ke121 sampai datum ke-160. Datum ke-161 sampai ke-197 dijadikan satu kelompok.

2. Selanjutnya, dalam masing-masing kelompok, data diurutkan berdasarkan lintang dan dipisah menjadi empat bagian. Setiap bagian menjadi memiliki 10 anggota, kecuali bagian terakhir (kotak 20, Gambar 2, kiri) dibuat hanya beranggota 7 titik.

3. Selanjutnya identitas bagian dibuat seperti pada Gambar 2 (kiri).

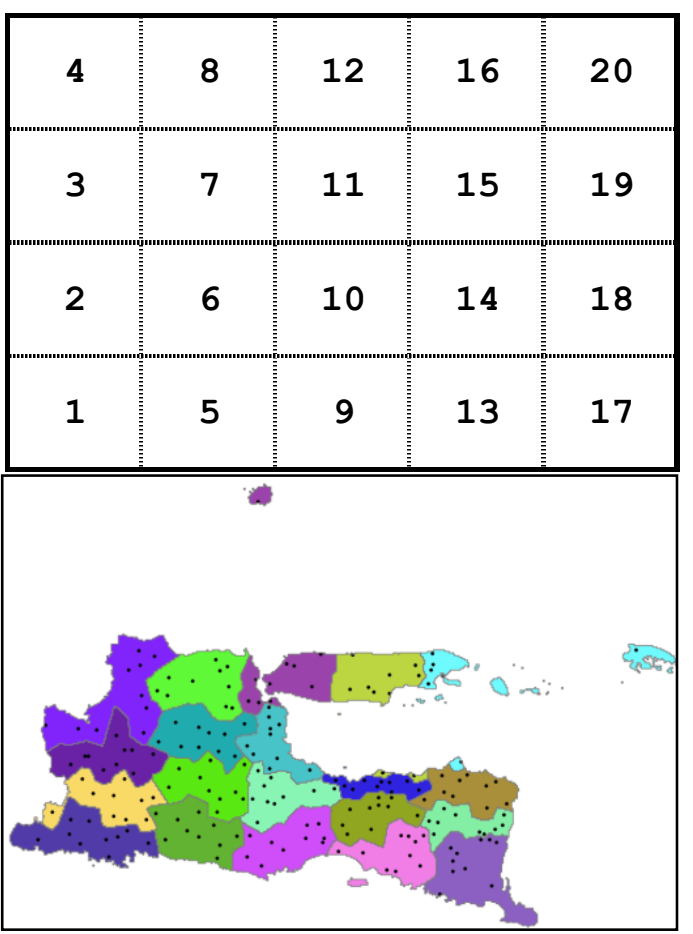

Gambar 2. Skema identitas bagian (kiri) dan hasil pemisahan (kanan, warna hanya sebagai pembeda)
Identitas bagian kemudian diperlakukan sama seperti angka klaster. Pengurutan kemudian dilakukan dengan menggunakan prioritas identitas bagian kemudian bujur lalu lintang. Dalam analisis selanjutnya, hasil pendekatan pemisahan ini disebut PIS.

Untuk mengetahui seberapa handal kelompok bahan validasi silang, dilakukan dua pendekatan, tidak adanya pertetanggaan terdekat dan jarak yang lebih jauh. Konsep tidak adanya pertetanggaan terdekat artinya semakin sedikit titik-titik yang dihilangkan berbatasan langsung, semakin baik. Agar subjektivitas dapat dikurangi dalam menilai ada tidaknya batas langsung, digunakan poligon voronoi (Aurenhammer dan Klein, 1998) sebagai bantuan pembuat batas. Batas dalam studi ini dibatasi menggunakan poligon voronoi yang dapat menunjukkan titik observasi terdekat dari suatu titik bebas.

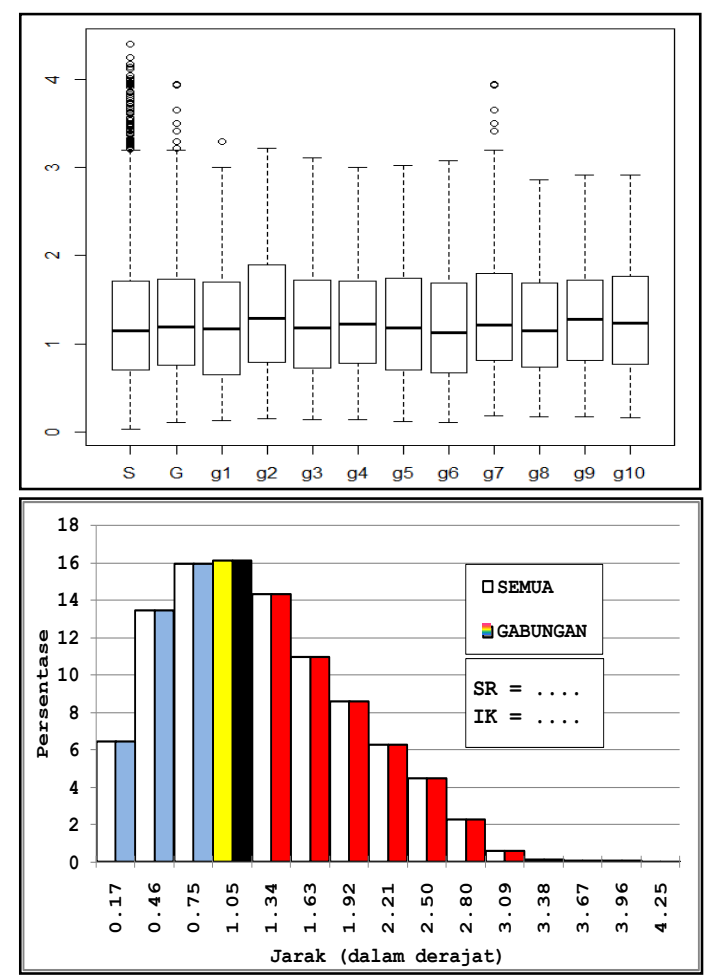

Gambar 3. Contoh plot boks dan histogram

Identik dengan konsep pertama, konsep ke dua juga membahas titik-titik yang dihilangkan dari suatu metode penyusunan, tapi berdasar pada jarak. Pertama, plot boks 
digunakan untuk mengetahui apakah jarak antar titik yang dihilangkan dalam suatu kelompok ( $g 1, g 2$, dan seterusnya) merata atau tidak. Persentase ada tidaknya kenaikan dari lima parameter (batas bawah, kuartil 1, median, kuartil 3, dan batas atas) plot boks akan dijadikan bahan pertimbangan. $G$ dalam Gambar 3 (kiri) adalah data gabungan dari $g 1, g 2$, sampai dengan $g 10 . S$ adalah seluruh jarak antar titik dari 197 titik.

Adapun histogram digunakan untuk memberikan gambaran jumlah jarak antar titik yang dihilangkan dalam kelas interval tertentu. Karena akan digunakan sebagai perbandingan, pembagian kelas yang digunakan adalah sama untuk semua histogram mengikuti rumus berikut (Struges, 1926).

$$
C=\frac{R}{1+3.332 \log N}
$$

Dengan $C$ adalah interval kelas, $R$ adalah selisih jarak antar titik terjauh dan terdekat dari seluruh 197 titik, dan $N$ adalah jumlah data yaitu 197. Dalam histogram, nilai tengah tiap kelas ditunjukkan pada sumbu mendatar sedangkan sumbu vertikalnya menunjukkan persentase. Histogram dalam studi ini digunakan untuk mengetahui ada tidaknya pergeseran distribusi ke arah kanan (jarak yang semakin jauh).

Untuk mempermudah analisis pergeseran distribusi, dikembangkan dua jenis indeks. Indeks yang pertama disebut selisih rata-rata $(S R)$. SR menunjukkan selisih rata-rata gabungan jarak titik-titik yang dihilangkan $(\bar{G})$ dari suatu metode penyusunan dengan rata-rata jarak seluruh titik $(\bar{S})$ sehingga dapat dirumuskan sebagai berikut.

$$
S R=\bar{G}-\bar{S}
$$

Adapun indeks ke dua yang dikembangkan adalah indeks kenaikan (IK) yang didefinisikan sebagai jumlah selisih dari persentase kanan modus $\left(\sum \Delta_{\text {kanan }}\right)$ dikurangi jumlah selisih dari presentase kiri modus $\left(\sum \Delta_{\text {kiri }}\right)$. Gambarannya adalah sebagai berikut.
Pada Gambar 3, persentase distribusi dari jarak antar 197 titik (S) adalah batang berwarna putih sedangkan kelas modus dari $\mathrm{S}$ berwarna kuning. IK dihitung dengan menjumlah seluruh nilai batang merah dikurangi seluruh nilai bagian putih sebelah kanan modus dikurangi jumlah seluruh nilai batang biru dikurangi nilai bagian putih sebelah kiri modus. Atau secara matematis dapat dituliskan sebagai berikut.

$$
\begin{gathered}
I K=\sum \Delta_{k a n a n}-\sum \Delta_{k i r i} \\
\Delta_{k a n a n}=G_{k a n a n}-S_{k a n a n} \\
\Delta_{k i r i}=G_{k i r i}-S_{k i r i}
\end{gathered}
$$

Semakin tinggi SR dan IK, semakin bagus metode penyusunan.

\section{HASIL DAN PEMBAHASAN}
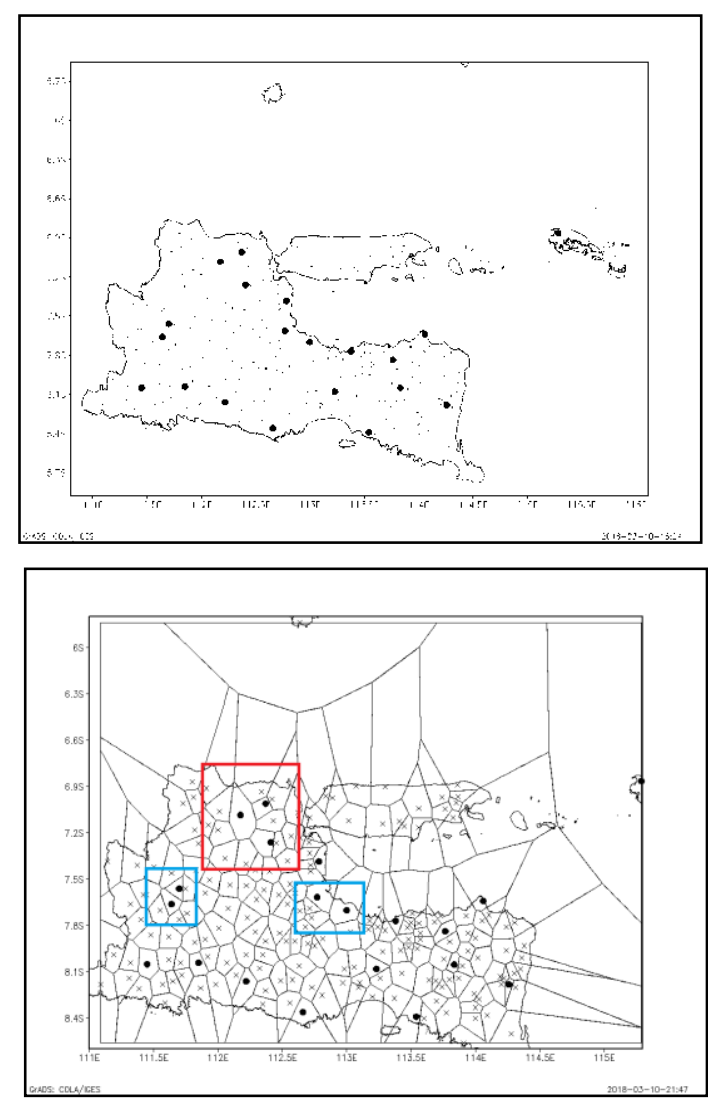

Gambar 4. Gambar titik yang dihilangkan K49 g7 tanpa poligon voronoi dan dengan poligon voronoi (kanan). 
Gambar di atas merupakan contoh analisis visual dengan memanfaatkan poligon voronoi. Titik hitam menunjukkan titik yang dihilangkan sedangkan tanda silang (x) menunjukkan bahan validasi silang. Ada tidanya pertemuan batas antar titik yang dihilangkan menjadi lebih jelas menggunakan poligon voronoi. Kotak merah pada Gambar 4 kanan menunjukkan adanya dua perbatasan langsung antara titik yang dihilangkan sedangkan kotak biru menunjukkan adanya satu perbatasan langsung.

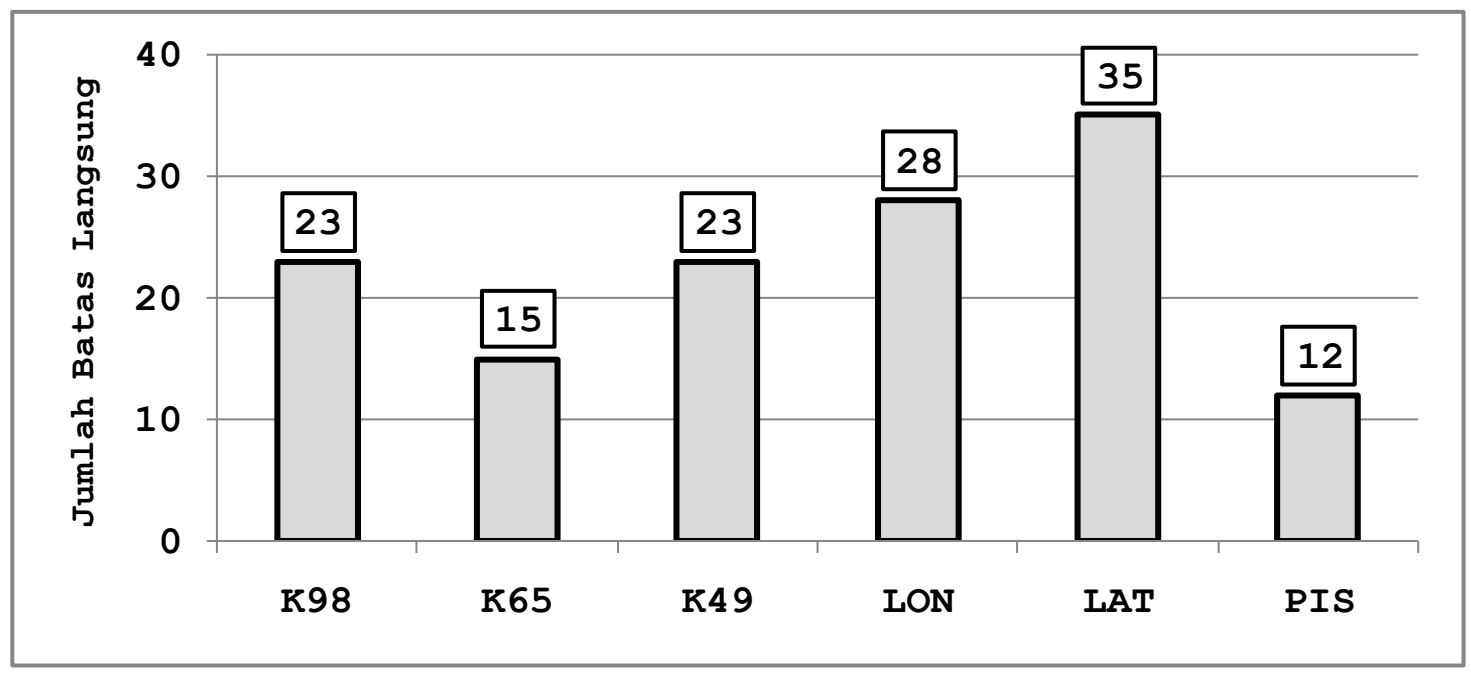

Gambar 5. Grafik jumlah batas langsung tiap metode 
Penyusunan menggunakan PIS terlihat lebih baik dari seluruh percobaan yang ada. Nilai batas langsung hanya terdapat 12 , artinya jikalaupun dilakukan modifikasi untuk menghilangkan batas langsung tersebut, hanya dibutuhkan maksimal 12 kali pengerjaan secara manual. Secara umum juga dapat terlihat bahwa penggunaan klastering dapat menurunkan jumlah batas langsung dibandingkan hanya bermodal pengurutan menggunakan koordinat (LON dan LAT).
Karena dalam analisis selanjutnya akan digunakan rata-rata, analisis eksploratori data (Bluman) dilakukan terlebih dahulu menggunakan plot boks untuk memastikan setidaknya arah dari pergeseran distribusi tidak hanya dihasilkan oleh beberapa pencilan data. Secara umum dapat terlihat bahwa dari plot boks tidak mayoritas median tetap berada di sekitar median data jarak keseluruhan

$(\mathrm{S})$.
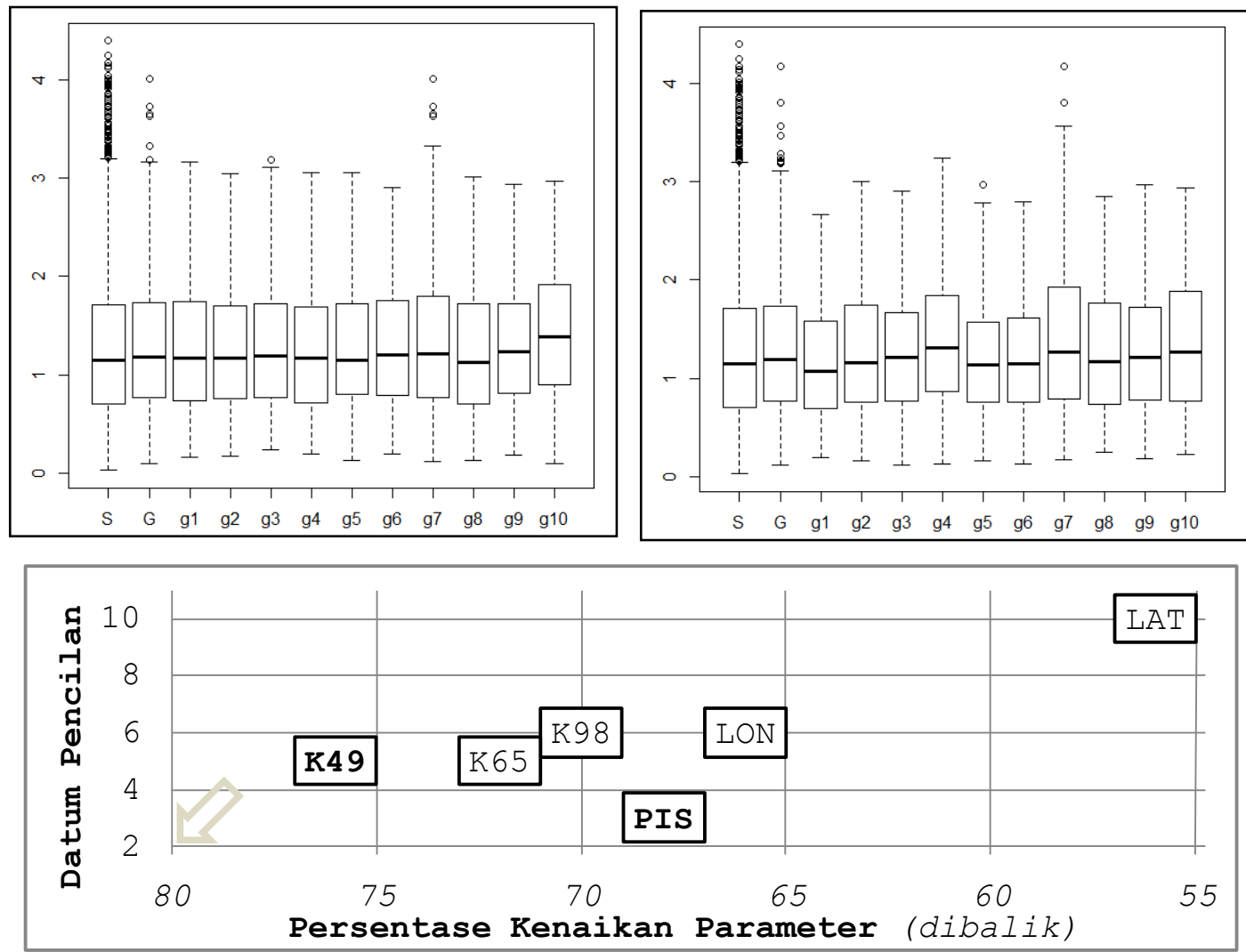

Gambar 6. Hasil analisis plot boks K49 (atas kiri) dan PIS (atas kanan) serta plot pencar rangkuman analisis 
Kondisi paling ideal ditunjukkan dari tanda panah dan karena skala antara sumbu mendatar dengan sumbu vertikal berbeda, skala tidak menunjukkan prioritas.

Metode K49 paling baik dilihat dari persentase kenaikan lima parameter dari plot boks. Metode PIS memiliki hanya memiliki tiga pencilan (paling baik) meski jika dikaji secara parameter plot boks, kenaikan persentase dari lima parameter pada kelompok data $g 1, g 2$, sampai dengan $g 10$ tidak sebaik metode berbasis klastering. Namun metode PIS masih tetap lebih baik dari LON maupun LAT dalam dua parameter di atas. Bahkan jika melihat bahwa penggunaan selanjutnya adalah untuk interpolasi, pemerataan distribusi jarak antar titik yang dihilangkan sebenarnya lebih utama dari sekadar memperjauh jarak antar titik yang dihilangkan.

Di sisi lain dapat terlihat pula kekurangan dari penggunaan klastering yaitu hasilnya sangat bergantung dari pemilihan ambang batas jarak pengelompokkan. Terlihat pada hasil sebelumnya (Gambar 5) nilai K65 lebih baik dari K49, namun pada Gambar 6 justru K49 yang lebih baik. Meski secara umum klastering terbukti lebih baik dari LON dan LAT dalam konsep tetangga berdekatan maupun jarak, inkonsistensi hasil akibat pemilihan jumlah klaster memerlukan kajian yang lebih lanjut.

Dari pola yang ditunjukkan dalam plot boks, dapat tersirat bahwa jarak hasil penyusunan akan lebih jauh dari rata-rata jarak keseluruhan. Akan tetapi untuk memastikan, analisis histogram dilakukan.

Hasil dari histogram menunjukkan pola distribusi yang relatif sama dari semua metode penyusunan. Dibandingkan dengan pola distribusi dari semua jarak, juga masih terlihat persamaan pola distribusi, yaitu agak menceng

ke kiri, seperti pola distribusi gamma dengan parameter alfa sekitar dua sampai dengan empat (Wilks). Adapun hasil lainnya dapat dirangkum dalam tabel berikut.
Tabel 1. Tabel SR dan IR

\begin{tabular}{ccccccc}
\hline & K98 & R65 & R49 & ION & LAT & PIS \\
\hline SR & 0.04 & 0.04 & 0.04 & 0.04 & 0.01 & 0.04 \\
IK & 4.35 & 4.08 & 5.27 & 5.00 & 1.80 & 4.62 \\
\hline
\end{tabular}

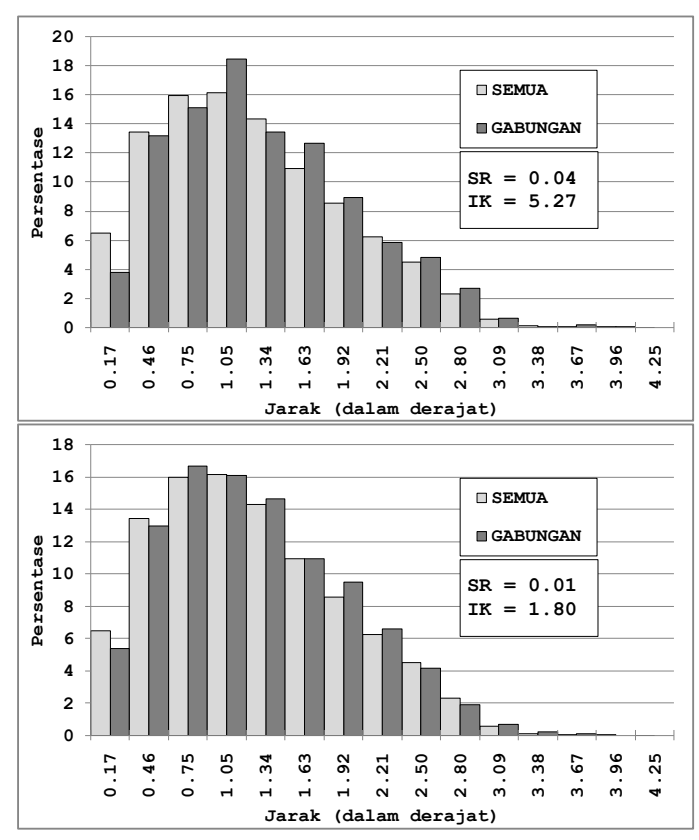

Gambar 7. Histogram K49 (kiri) dan LAT (kanan)

Indeks SR menunjukkan bahwa semua metode penyusunan memiliki jarak antar titik yang dihilangkan lebih jauh dari rata-rata jarak keseluruhan. Namun tidak adanya variasi yang baik dari parameter ini menunjukkan bahwa parameter ini tidak terlalu signifikan untuk digunakan sebagai penentuan bahan validasi terbaik. Di sisi lain, IK menunjukkan kemampuan yang lebih baik dengan menghasilkan nilai yang lebih beragam. Metode penyusunan berbasis klastering kembali menunjukkan inkonsistensi. Pada histogram, dua dari tiga metode berbasis klastering tidak lebih baik dari LON dan LAT. Hal ini menambah bukti bahwa pemilihan jumlah klaster berpengaruh terhadap bahan validasi silang yang dihasilkan.

Secara umum dapat terlihat bahwa pada konsep pertetanggaan terdekat, PIS unggul, sedangkan untuk konsep jarak terjauh, K49 lebih baik. 
Namun, karena metode berbasis klastering tidak menunjukkan konsistensi yang baik, maka dalam studi ini dapat dijustifikasi bahwa metode PIS adalah yang paling handal dalam penyusunan bahan validasi silang. Oleh karena itu, langkah yang selanjutnya dilakukan adalah melakukan modifikasi terhadap hasil dari metode PIS.

Modifikasi dilakukan dengan bantuan piranti lunak sistem informasi geospasial QGis Wien 2.8 untuk mendapatkan kemungkinan pertukaran urutan. Karena hasil bagian sudah bergerombol pada suatu kotak, pertukaran dapat dilakukan dengan mencari titik bernomor yang tidak sama angka terakhirnya. Hasil dari pertukaran tersebut adalah sebagai berikut.

Tabel 2. Pertukaran urutan pada hasil metode PIS

\begin{tabular}{|c|c|c|c|c|c|}
\hline NO & \multicolumn{2}{|c|}{ TUKAR } & NO & \multicolumn{2}{c|}{ TUKAR } \\
\hline 1 & 1 & 3 & 6 & 64 & 69 \\
2 & 2 & 4 & 7 & 82 & 84 \\
3 & 15 & 16 & 8 & 115 & 120 \\
4 & 33 & 37 & 9 & 122 & 123 \\
5 & 54 & 55 & 10 & 145 & 149 \\
\hline
\end{tabular}

Jumlah modifikasi ternyata tidak sampai dua belas. Dengan menukar urutan 115 dan 120, ternyata tiga batas langsung dapat dihilangkan. Sehingga hanya dengan menambahkan sepuluh modifikasi di atas, didapatkan bahan validasi silang yang titik-titik hilangnya tidak ada yang berdekatan satu sama lain. Hasilnya dapat dilihat pada lampiran.

\section{KESIMPULAN DAN SARAN}

Dari diskusi di atas dapat ditunjukkan bahwa pendekatan menggunakan pemisahan merupakan metode yang paling sesuai. Metode klastering memilki inkonsistensi yang terkait dengan pemilihan jumlah klaster. Dengan menambahkan sepuluh modifikasi, didapatkan bahan validasi silang yang dapat digunakan untuk uji komparasi metode interpolasi. Meski dalam perkembangan ke depan sistem kecerdasan buatan yang mengandalkan kecepatan komputasi dapat unggul dalam hal operasional, namun pembentukan algoritma dan materi untuk pendidikan tetap akan dibutuhkan. Kajian penyusunan kelompok-kelompok bahan validasi silang yang bukan leave one out secara tidak random dapat menjadi salah satunya. Berbagai skrip disusun untuk analisis maupun untuk menghasilkan gambar dalam jumlah banyak dalam studi ini menggunakan piranti lunak GrADS dan $\mathrm{R}$ statistic. Diharapkan pengembangan lebih lanjut terhadap pemanfaatan piranti lunak tidak berbayar ini dapat dikembangkan lebih lanjut juga. Adapun metode penentuan bahan validasi silang yang paling direkomendasikan menurut penulis adalah poligon voronoi dengan menggunakan GrADS.

\section{Ucapan terima kasih}

Ucapan terimakasih kami sampaikan ke keluarga besar Stasiun Klimatologi Malang yang menjadikan studi ini dapat dan perlu dilakukan. Ucapan terimakasih banyak juga kami haturkan kepada Bapak Supari, Badan Meteorologi Klimatologi dan Geofisika, yang menginspirasi dilakukannya studi ini.

\section{DAFTAR PUSTAKA}

Hengl, T. 2009 A Practical Guide to Geostatistical Mapping, Luxembourg: Office for Official Publication of European Communities.

Adhikary, S. K., Muttil N., dan Yilmaz A. G. 2017, Cokriging for Enhanced Spatial Interpolation of Rainfall in Two Australian Catchments, Hydrological Processes, 2143-2161.

Aires, F., dan Prigent, C. 2007. Sampling Techniques in High-Dimensional Spaces for the Development of Satellite Remote Sensing Database, Journal of Geophysical Research, 112, D20301, doi:10.1029/2007JD008391.

Aurenhammer, F., dan Klein, R., 1998, Voronoi Diagrams, dalam Sack dan Urrutia, 
Handbook of Computational Geometry, Elsevier, Amsterdam.

Bluman, A. G. 2007. Elementary Statistic : A Step by Step Approach, New York: Mc Graw-Hill.

Borges, P. D., Franke J., da Anunciacao Y. M., Weiss H., dan Bernhofer C. 2015 Comparison of Spatial Interpolation Method for the Estimation of Precipitation Distribution in Distrito Federal, Brazil. Theor. Appl. Climatol, DOI 10.1007/s00704-014-1359-9.

Bostan, P. A., Heuvenlink, G. B., \& Akyurek, S. Z., 2012, Comparison of Regression and Kriging Techniques for Mapping the Average Annual Precipitation of Turkey, International Journal of Applied Earth Observation and Geoinformation , 19, 115126.

Falivane, O., Cabrera L., Tolosana D. R., dan Saez A. 2010. Interpolation Algorithn Ranking using Cross-Validation and the Role of Smoothing Effects : A Coal Zone Example. Computers \& Geosciences, 512519.

Kidd, C., Becker A., Huffman G. J., Muller C.L., Joe P., Skofronick-Jackson G., dan Kirschbaum D.B. 2017. So, How Much of the Earth's Surface Is Covered by Rain Gauges?. Bull. Amer. Meteor. Soc., 98, 6978.

Majani, B. S. 2007. Analysis of External Drift Kriging Algorithm with Application to Precipitation Estimation in Complex Orography, Thesis, Netherlands: ITC.

Sturges, H. A. 1926. The Choice of a Class Interval, Journal of the American Statistical Association, 21, 153, 65-66, http://www.jstor.org/stable/ 2965501.

Taesombat, W., dan Sriwongsitanon N. 2009. Areal Rainfall Estimation using Spatial Interpolation Techniques, Science Asia, 268-275.
Wilks, D. S. 2006. Statistical Methods in the Atmospheric Sciences, London: Academic Press. 